\title{
Bread and Knowledge Politics E. P. Thompson (1924-1993)
}

\section{Philip Corrigan ${ }^{1}$}

\section{Preface: A Tribute to Thompson and a Note on Philip Corrigan}

The issue of influence is a complex one, and certainly not linear, especially where someone like E. P. Thompson is concerned. Generations of historians, others interested in an interdisciplinary approach, for example in historical sociology, writers and activists in the left ranging from party members to libertarian marxists and/or peace activists have grown up reading Thompson, being in the orbit of his political/intellectual influence. His vindication of the common man, the working people, and their historical agency, and the polychromatic nature of their consciousness, opened new ways of thinking about class and class consciousness. He shifted the gaze of the left from Stalin or Lenin to William Blake and William Morris and moved revolutionary politics from the prison house of positivism and functionalism to the realm of imagination and utopia.

And yet influence worked, as it always does, in complex ways. As they grew in their work and politics, entering through the door that Thompson largely helped to open, the new writers and historians went further and actually matured by responding to him both in agreement and in critique. One of the most interesting members of that school is Joan W. Scott, working in difference in the face of Thompson's rather abstract notion of equality between men and women in Gender and the Politics of History (1988). In a chapter specifying her critique, "Women in The Making of the English Working Class," Scott voices a difficulty pervasively experienced by feminist historians about Thompson's historical-political project:

In this connection it is revealing to note the absence in the book (and in the preoccupation of the audience to whom it was addressed) of questions that have since become troubling for some labour historians; these are questions that were posed by the feminist movement of the late 1960s and early 1970s (well after the publication of the book) about the historical role of women. When one rereads The Making of the English Working Class now, one is struck not by the absence of women in the narrative but by the awkward way in which they figure there. (71)

If the difference created by gender organization did not have much room in Thompson's schema of history-making despite the presence he accorded to women, other differences, of race, for example, or sexual orientation were beyond the margin of his ecstatic Muggletonian Marxism. And yet the importance of the role he accorded to consciousness in forging revolution, to passion and vision, to living one's politics, to the creation of a history from below, continue as his contribution. So real is this

1 On the news of Edward Thompson's death Philip Corrigan scrapped the article he was working on for left history and sent us this immediate tribute. We hope to publish other material of his at a later date. Himani Bannerji has provided the following preface. 
that his death is experienced as a personal loss by many who never knew him personally, and certainly by those who did, for whom he was a singular reference point, the magnetic north of politics and history.

One such person is Philip Corrigan, a historian who elaborated Philip Abrams' conception of historical sociology, and with Derek Sayer, delved into the realm of morality and traced its institutional or regulatory path in English state formation. What we have is a dialogue constructed by Corrigan with Thompson. It is especially interesting for us given who Corrigan is, to which he speaks in this text when he situates his father next to Thompson. A child of working-class Irish parents, an organic intellectual of the people of Thompson's history project, Corrigan here defines himself, his own politics and history, his own intellectual development in making difference. And he does so in reference to Thompson. Admittedly personal, and/therefore, political, his negative dialectic offers us the betrayal of the English working class by Thatcherism - "Phil, they are telling us lies" - and also an uncensored view of the making of Philip Corrigan - the author of Human Capacity/Human Development, co-author of The Great Arch, Socialist Construction and Marxist Theory, For Mao among others - by Thompson, by Williams, by his reading of Mao (someone Thompson would not give much room or respect). And this is not a simple urge for expression, using Thompson's category for bourgeois/petty-bourgeois self-indulgence, but a text produced in accordance with the deepest meaning of the Thompsonian sense of the notion of rational, a characteristic he was not shy about using for John Muggleton or William Blake. The self in relation to its other, involved in the process of exclusion and inclusion, of definition and recognition, becomes the divining rod for the waters of time and history.

Himani Bannerji

5 October 1993.
121
$1 \mathbf{l}$
ll l

Question: Are the working classes better satisfied with the institutions of the country since the change has taken place?

Answer: I do not think they are. They viewed the Reform Bill as a measure calculated to join the middle and upper classes to Government, and leave them as a sort of machine to work according to the pleasure of Government.

(From a 1835 Select Committe Report, quoted by E. P. Thompson in The Making of the English Working Class)

Slipped into a brief news bulletin from B.B.C. Radio about 3 p.m., 29 August 1993 (although he had died on 28 August), the announcement that "the peace activist and historian E.P. Thompson had died, after a long illness, at his home in Worcestershire." On later bulletins the 'item' included a tribute for Edward's work in and for the peace 
movement by Bruce Kent (CND, END). I wept - unsure why - I wept nonetheless. The weeping reminded me of E.P. Thompson's own mention of his crying, in one of those (there are so many) essays, here, about how 'They' were trashing the years 1939-1945 (and, by extension, the years from 1945 to - at least - 1947/8, as well). He spoke of suddenly crying, in the kitchen, doing the washing up, preparing and cooking a meal; suddenly crying. Not only do I now cry like that, quite uncontrollably, and a lot of tears, at the trashing and brutal denial of so much that I have not only lived but consider a bare minimum, albeit social democratic, for any possible justice (towards a Just Society, for a more equal sociality); but then so did my father - born a generation before E.P.T. - and Dad died in 1986. For the last five or so years he had kept a notebook by the chair, so he could note down 'facts' from the newspaper, from the radio, from the television news. He told me: "why Phil, they're telling us lies; look I've written it all down." Like me, then and now, he shouted at the television, railed against the radio; he often wept. I would like now to hold him, hug him; only once did I do so, when he had broken his pelvis and I had to lift him into a chair to await doctor and then ambulance.

Like so many, and like E.P.T., Dad knew both what (and who) was 'at issue' ('at risk') and saw that all he and his father (Big Jim Corrigan, early member of the Woolwich Labour Party, the Royal Arsenal Co-operative Society, Plumstead Radical Club, and Senior Shop Steward of the 30000 so-called 'unskilled' workers in the Royal Arsenal, one of the largest factories in the world, in Woolwich, South East London, England), had worked for, with millions of others, in a politics of Hope, was not just being destroyed (that, in a militant sense of class struggle, where all 'our' gains are all ways tentative, is less hurtful) but rubbished, ridiculed, laughed at, dismissed. My weeping, your weeping, Edward, and his weeping. Men still cry, though less openly perhaps than once they did.

Strange, Edward, to think you've gone, ${ }^{2}$ all hair, visage, eyes and voice - above all that 'voice' in sound and in print - an incredible, sometimes, at times, a 'too muchness' about you, but all ways a thereness: frission, engagement; excitement, however much I disagreed, as so often I did. The humour, the rhetoric, the images, the metaphors and the solid withering gaze turned to (and thus turning us toward) 'Them': what are THEY doing or trying to do with 'our' lives and why do 'They' feel 'They' CAN do all of that to 'US'?

By the mid 1960s I did know 'of" 'you, I think "The Peculiarities of the English" 3

2 Some readers may be aware that this is also saying Kaddish; for the example which most influenced me, listen to Allen Ginsburg "Kaddish" on the 1960s recording of him reading his own poems.

3 Originally in the Socialist Register (1965) in a fuller version of Thompson's Poverty of Theory (1978). Originally located as part of a debate between the newer and older editors of New Left Review, but any reading shows it to be also a critique of some former comrades within the CPGB Historians Group, eg., his denunciation of any singular and totalizing 'The' Revolution. This essay donated the title and much, much more besides to Philip Corrigan and Derek Sayer, The Great Arch (Oxford and New York 1985; Amplified Edition Oxford and Cambridge 1991). An earlier, very edgy, tribute to this essay is to be found in Philip Corrigan, "Towards a History of State Formation in Eighteenth-Century England," 
(a writing of yours to which I have returned and returned). I crisscrossed my reading of you with that of Raymond Williams (1921-1988). Yes I do know of your initial distancing from him, your sneering review of his Long Revolution in an early New Left Review. Is there not a touch here of your either/or politics, total acceptance and agreement or that person is expunged, into one of the seven levels of Hell for them? Later, though, I met both you and Raymond at that wonderful weekend school in Bristol in 1975, I think; and, in between the formal lectures (yours was a sort of early Poverty of Theory, Raymond's a version of Marxism and Language) I talked with you both, but by then we must have corresponded, somewhere. Like Magnus Pyms carrying around of his father's filing cabinet, I have a black briefcase full of my letters to you.

I know that the 'little pamphlet' which Val Gillespie and I wrote, so energised by your work - "Class Struggle, Social Literacy, Idle Time" (Brighton 1978) originally finished in 1974, was discussed with you and sent to you. But Val and I suffered the long march through the left/radical/historical journals. Later the text surfaced in what was effectively (and effective it was in the underground in the U.S.A. and Canada) a samizdat form. But, Edward, I wondered then and now how much you ever thought that there were organized exclusions and silencings here and not just 'there' ('The East'?).

But then, like a completely different sort of music, came your crucial essays of the 1970s and 1980s. You see, Edward, I'd always seen your work as a crucial contribution to theory, not just historiographical (though clearly there too) but sociological and social and marxist. Yes, I know you did not like the word theory, but, what I learned from Philip Abrams (and then found there in Mannheim, as indeed in Marx, of course) as historical sociology was what your multifarious workings were about. As I think so many (but I emphasize not all) in the Communist Party of Great Britain's Historians' Group did, but so much more so (and was this not sometimes a threat for you, Edward?) in the tremendous resurgence and discovery and articulation of different historiographies and histories through the late 50s. I do not subscribe to any theory of the major significance of the later 1960s. Far more went on, and importantly so, between 1956 and 1966, than afterwards (and that is my dogmatism!) and the early 1960s. Where, to argue otherwise, do people think Great Leaps Forward come from? From years of exercising, from training, from finding out.

In this era of fashions, the steady work of that decade is comprehensively remarkable, both for what surfaced (after long gestation); during it and during which time other startlingly original work was being simmered, cooked, brewed, put together and constructed. Your William Morris preceded both Raymond Williams Culture and Society and Richard Hoggarts Uses of Literacy. Three male texts that rounded 'A Revolution,' I do not deny you, them, or 'It', but cannot fail to notice the exclusions present not just in these three texts, but in the whole tapestry of sorts of history, sorts of socialism, sorts of cultural studies that they helped to found. It has taken a lot of work, by voices and persons customarily ignored and denied and 
silenced, to make those partialities visible and even now, almost forty years later, the latter critiques are still taken as if all we need is to add-them-on: mentioning women more often, don't forget blacks, and, gosh, do we have to talk about hegemonic heterosexuality, and, even, surely not! occidentalism, thus racism. A profound stigmata stretches across all that work, like a blood trace, as Marx said, below the writing, seeping out how the three great world systems of racism, sexism and classism have to be made manifest, witnessed.

But all that said, the later, conventionally called 'post-1968' period was one of the most increasingly visible arguments for quite different histories (as sociologies, politics, aesthetics, etc). I would depict them all, clumsily, as OPPOSITIONAL rather than alternatives: from the contributory writers and groups of the Federation of Worker Writers and Community Publisher, ${ }^{4}$ through the local, sectional and national activities of all sorts of History Workshop, and all those denied voices who struggled to have their stories recognised. As Stephen Yeo later wrote "Whose Story?" 5

But, again, but, Edward, you and I disagreed, then, just then, about that which you considered within 'The Queen' before that somewhat horrific episode in the discussed Church in Oxford (your words are preserved, mine are not, but you name me and my sin in your excommunication 6 ) in a little squib called "On Not Writing On the Back of New Postage Stamps": History is a cultural form. It is a site of struggle over what/who counts (and thus, what and whom is discounted and denied). You recognize this, though typically without apology, in your latest work: Customs in Common. There in various places, but most solidly in your response to critics of your earlier "Moral Economy of the English Crowd," you argue that there are variable cultural forms of history, ways of doing history.

So, to critically memorialize, to strongly urge the necessity of reading, agreeing, arguing with and then going beyond, you now seem to agree that histories (which may be herstories) are all ways already becoming; they are never finalised beings. First, yes, and of course, you taught us, there is the need to go beyond conventional (and conventionalised) accounts with their enormous condescension of posterity, towards the majority of human beings then alive and alive now. We have to work against their rubbishing, the laughing off which equals the laughing away that is erasure of all those differential and particular and significant other histories, of different voices, actions, beliefs, behaviours, which become congealed behind a constructed history, which passes itself off as natural, normal, universal and obvious. That is, to follow both you and that neglected historian Raymond Williams, where the selective memorialization of the few comes to stand and becomes the history of all. That is to say, again, all practices of exclusion and denial are practices of inclusion and celebration and it is surely time now, in 1993 that these smug, academical, rewarded and hegemonic practices were thoroughly BLOWN AWAY! But, thus far,

4 Cf. D. Morley and Worpole, eds., The Republic of Letters (Comedia 1983).

Journal of Contemporary History (1986).

6 See the Closing pages of R. Samuel, ed. Socialist Theory and People's History (London 1979).

7 Past and Present (50) 1971, and a later version in Customs and Commons (London 1991). 
more attention (perhaps of necessity) had been paid to the two senses of exclusion first of being hidden from history, in the work of Sheila Rowbotham; ${ }^{8}$ second, in the work of Philip Abrams, an exposure of the vicious insanity of boundarising and patrolling the walls between the studies of The Past and The Present. ${ }^{9}$ Both exclusions work very carefully (one, might also say, caringly) to deny validity to any senses of the Past (as folklore, popular memory, antiquarianism, and all Histories preceded by an adjective, e.g. local, regional, economic, social, political, etc.) from the sacred groves of HISTORY. Still, to this day, the historicalness of affective and somatic knowing, and ways of seeing, are being denied. Secondly, all such denials, without of course being mentioned, invert as a 'proper' methodology for historiography. That is to say not only what has to be studied, but what/whom is to count as evidential is prescribed. And, I do not need tell you, every prescription is aiso a proscribing, a declaration of the irrelevance of 'The Rest' (of Humanity), 'Les autres' here as so often, in modern talk being mere noise compared with the steady signal of valid evidence.

But, again, here is where, you and I so powerfully and initially disagreed: there is no one History to be made up, to be fabricated, to be set-up. ${ }^{10}$ You cannot, as I once suggested polemically, by scattering a few Hobsbawms amongst the Hartwells, produce THE (true, valid, universally all ways correct) History of THE Industrial Revolution. You see, at times (perhaps rather too many times), Edward, you did act and talk and speak as though you had, once-and-for-all, 'got it right' and all else was either old reactionaries (whose polemical demolition we could cheer from the sidelines, or, worse, within the gladiatorial amphitheatres) for revolutionaries. We talked of this a lot, and there are one or two sentences in the introduction of The Poverty of Theory which speak back to me, your denying that this is playing a generation game. This is not to deny, for a moment, the value of texts that moved me most (those of polemic I have mentioned), but also your Morris (in the 1955 and later revision, including the New Left Review essay) and your caring tribute to Christopher Caudwell. ${ }^{11}$

Second, a stress on the importance of ranges of evidence, more importantly, on the need for evidence to challenge the partial, limited 'versions' that attempted to claim a totality of truth. Such that, they wanted to argue, there was nothing more to say: no further story to tell, no need for more research. This latter is important since the bulk of recognised History, until very recently, came out of institutional apparatuses in which supervisors told graduate students that such and such had 'done' $X, Y$ or Zor, equally narrowing, made them trace up the details and byways of some bloody great motorway which they, the supervisors, had established as their own. So we have either no challenge or what Roland Barthes called decoration, supplementation.

8 Hidden From History 3rd ed. (London 1977).

9 Historical Sociology (London 1982) and his 1977 paper "Notes on some difficulties in studying the State," Journal of Historical Sociology 1(1) 1988.

10 Philip Corrigan, "Setting Up The Seen," in J. Melling and J. L. Barry, eds., Culture in History (Exeter 1992).

11 Socialist Register (1978). 
But you could never really accept those who were neither disciples nor acolytes, but were further workers, whose resources began with yours, but moved on. You never had any need to 'rear' away from them, from me, from us, in fearful denial. Here, of course, I touch on at least two of your constructed enemies and fears: feminist historians (feminism tout court!) and sociological uses-and-critiques of your work. Why could you not join in comradely conversations about this, not preaching from a pulpit, protected by John Saville, as you did in that terrible moral and political dispersion on the left? How can, more bluntly, any of us, get it right, your way? But does there have to be one way?

Thirdly, there is always more to be found out and thus thought through in terms of all the existing historiographic and historical claims. This I take to be the organic link between your investigation of the $1780 \mathrm{~s}-1830$ s, the eighteenth century, your wonderful essays against the spirit and ethos of The Age (about juries, about justice, about the police, about secrets, about the denying reconstruction of the years of the Second World War and the Labour Government 1945-48).

But that said, and this is for you, after all, Edward, I wondered always where you stood in relation to that crucial modality of history: the inventing/imagining literatures $^{12}$ from the 1970s onwards, although with of course major antecedents (some of which you have, indeed, brought back to the Light from L'enfer within the Public Record Office of the Department of Printed Books of the British Museum). Most recently, (and too recently for you?) Aijaz Ahmad's In Theory ${ }^{13}$ has certain affinites with The Poverty of Theory's main essay, but also major differences.

You see for me, that sort of writing, films, theatres, musics, poems, readings, quite generally enables, and empowers, a certain social force, a form of solidarity-energy, without which I do not conceive how we might even, quite faintly, begin to think of socialism. All I am saying, as old Lenin did, and so many forget it, of course, is "No dreams, no revolution." To show that some major ways of seeing, recording, thinking, organizing, hoping or having hopes altered or denied, are invented, are constructed; means they are not at all natural or fixed, but are, if invented, changeable. That is everything and all. And such literatures are for major global resources for they engage, have to delineate, all forms of oppression, exploitation, subordination and denial: patriarchal, racist, classist, age-ist, occidental, and resoundingly, heterosexist.

And, so, Edward, farewell, my friend and comrade. You did give strength to many

12 For a very preliminary list see references in Philip Corrigan "Power/Difference," Sociological Review (May 1991) and "My Place or Yours?" Journal of Historical Sociology 17/2 (1991).

13 Subtitled "Literatures/Nations/Classes" (London 1992). This, like the work of Trinh Minh Ha or K. A. Appiah, to take two examples, raises quite directly, and quite bluntly, and very unreasonably, why academics, revolutionaries and intellectuals never examine their own complicit relation with Occidentalism ('The West'), especially with their directed attention to how the Other(s) have been depicted, described, mapped, and discoursed. This, in the blinding control of the orthogonality of the set-up, leaves them/us/me in shadows behind the spotlights, beyond the camera, in that careful shadow which, perversely, enables us, within Occidentalism (in that circus! that zoo!) to hide in the light: look at me now, but I'm doing tricks on/with the Other(s)! Aren't I a clever boy! 
110 left history

of us, your smile, a word, a look of the eyes, trace of the body in your writing, in all sorts of ways to say, we are together now and here and here and now, and we are moving. It may seem odd to say, but this memorial says also: go well, take care, and lots of love and solidarity. AVE ATQUE VALE. 